\title{
Management of Character Education in Realizing Cadets Who Ethically in Politeknik Pelayaran Surabaya
}

\author{
Indira Maharani Putri1,a*, Erny Roesminingsih ${ }^{1, b}$, \& Eni Wuryani1,c \\ ${ }^{1}$ Department of Education Management, Postgraduate of the State University of Surabaya, Surabaya, Indonesia \\ a indiramaharaniputri93@gmail.com, ${ }^{b}$ ernyroesminingsih@unesa.ac.id, \& c eniwuryani@unesa.ac.id \\ ${ }^{*}$ Corresponding Author
}

How to Cite : Putri, I., M., Roesminingsih, E., Wuryani, E. (2019). Management of Character Education in Realizing Cadets Who Ethically in Politeknik Pelayaran Surabaya. International Journal for Educational and Vocational Studies, 1 (5), 479-483

\section{ARTICLE HISTORY}

Received: 11 June 2019

Revised: 21 July 2019

Accepted: 23 August 2019

\section{KEYWORDS}

Character Education;

Cadets;

Management of Character

Education;Politeknik

Pelayaran Surabaya

\section{ABSTRACT}

In this time, advances in technology and science are becoming increasingly dominant in changing character or actions and public trust. The impact of many problems that occur between children and adolescents is violence and acts of anarchy, theft, no matter the rules, fighting between students, disrespect, ways of using language and speaking poorly, low morale, lack of respect for parents and teachers, low sense of individual and citizen responsibility, and lack of compassion and respect among friends (Lickona, 2016: 20). Such conditions that make educational institutions raise the question of the extent to which he manages character education in students (Novitri, 2013). This research is an interactive type of qualitative method. The main data source in this study was obtained by snowball sampling. Data collection techniques in this study used three techniques, namely observation, interviews, and documentation. Politeknik Pelayaran Surabaya is a university that has a strong commitment to organizing character education programs. The conclusion of this study states that the management of character education in Politeknik Pelayaran Surabaya has been done well and effectively.

This is an open access article under the CC-BY-SA license.

\section{INTRODUCTION}

In this time, advances in technology and science are becoming increasingly dominant in changing character or actions and public trust. Global phenomena will be very easy to influence the younger generation, especially adolescents who are experiencing changes in conditions from children to adolescents, the search for identity periods with unstable emotional conditions, so that the impact can spur problems that are often encountered through television shows or directly.

The impact of many problems that occur between children and adolescents is violence and acts of anarchy, theft, no matter the rules, fighting between students, disrespect, ways of using language and speaking poorly, low morale, lack of respect for parents and teachers, low sense of individual and citizen responsibility, and lack of compassion and respect among friends (Lickona, 2016: 20). Such conditions that make educational institutions raise the question of the extent to which he manages character education in students.

Character education is a national movement that requires schools to score superior young people (Pala,-
2011). Therefore, character education must become an integral part of the curriculum, not be taught as a separate subject (Thompson, 2002). Formal education institutions are responsible for implementing character education. Because character education programs can have a positive effect on student behavior (Agboola \& Tsai, 2012). Positive behavior students must have is respect, truth, fairness, and responsibility (Skaggs \& Bodenhorn, 2006).

Advanced character education for secondary school students, one of which is Higher Education. This is based on Law Number 20 Year 2003 Article 19 Paragraph 1 which states that the university is one of the educational institutions that takes the task of achieving national education goals based on moral values derived from religion, Pancasila, and culture, so that it is expected that through character education in Higher Education can improve the quality and results of education that leads to the noble character and character of students in a complete and balanced manner in daily behavior, in accordance with graduate competency standards in each education unit. Universities in Indonesia in 2007 were 
classified by the Republic of Indonesia Ministry of Research, Technology and Higher Education in two groups, namely the polytechnic group and non-polytechnic groups (universities, institutes, and others).

Politeknik Pelayaran Surabaya is one of four official higher education institutions that have the vision to become an International Standard Superior Shipping Polytechnic. To fulfill this request, through study programs both academically and through the character building program given in extracurricular, intracurricular, and as a hidden curriculum activity in teaching and learning activities need to be given.

Politeknik Pelayaran Surabaya has care guidelines for Taruna/Taruni. In the guideline it regulates activities and rules of conduct for cadets. The schedule and rules imposed, it is expected to familiarize Taruna/Taruni to discipline and maintain their attitudes and behavior in society. With a more boarding school system it is possible to be able to prepare graduates' results to become reliable, professional and ethical sailors to meet the demands of national and foreign shipping companies.

Based on the results of interviews with the Head of the Character Development Center in planning one's character development to support the formation of Taruna/Taruni characters, each unit head must contribute. For example, planning a character education program made by the Head of the Psychology Unit is the Cadet Character Class program, Cadet Afternoon Speaking, periodic psychological tests, group counseling, and mentoring counseling.

The Cadet Character Class program is an additional training program held starting in 2017 for cadets third semester students from the Diploma III and DP III programs. Cadet Character Class Program is the responsibility of the psychological unit in collaboration with consultation actions aimed at forming cadets with the character "HERO", namely Humanism, Empathy, Respect, Outstanding.

The implementation of character education in the Politeknik Pelayaran Surabaya with learning habituation, as well as examples starting from catar (calon Taruna) with several stages, including: 1) the initial phase or orientation phase Taruna/Taruni must follow the basic period of character formation (Madatukar). Madatukar is an introduction to the goals, objectives and character building activities that will be carried out for approximately three months. As long as Madatukar Taruna/Taruni are not permitted to leave the campus environment, unless there are special cases and have permission from the campus. Taruna/Taruni activities are written in full in PERTIBTAR book, 2) the formation stage, this stage focuses on developing the character of cadets through supervision and maintenance, and 3) the last stage is the maturation stage, at this stage maturity is developing which gives birth to the nature of leadership.
Implementation of character education for the Cadet Character Class (CCC) program every Monday-Thursday in Taruna/Taruni learning hours with 2 face-to-face turns. Implementation of the Cadet Afternoon Speaking program which is held every day after learning so that cadets can improve their ability to communicate in English.

Other activities in forming character components are embedded and stand alone methods. Embedded activities are carried out in accordance with daily cadet activities (learning activities, co-curricular activities, extracurricular activities, cadet organization activities, on job training) and final project preparation, while activities that are stand alone methods are carried out through certain activities, namely cadet visits, outward bound, life plans, personal development training and mentoring.

Supervision at the Politeknik Pelayaran Surabaya in daily activities is carried out by responsible professionals, namely lecturers, advisors, tutors, lecturers, tutors, instructors, facilitators, and cadet caregivers (pasuhtar) in the classroom or in the dormitory. This is based on the opinion of Wiyani (2012: 61) that supervision is an effort to monitor systematically and continuously.

Evaluation is a form of activity aimed at finding the level of development of the quality of behavioral attitudes as well as correction of the behavior of Taruna/Taruni manifested in actions or speech.

Based on research conducted by researchers, some relevant research that is generally related to the author's research is as follows. Research was stated by: Freeman (2013) about The Implementation of Character Education and Children's Literature to Teach Bullying Characteristics and Prevention Strategies to Preschool Children: An Action Research Project. The results of this study as a bullying prevention for children aged 4-6 years with reading books and character education activities with the theme of bullying pre-school children.

Lee (2009) with the title The Planning, Implementation and Evaluation of A Character-Based School Culture Project in Taiwan. The results of this study focus on planning, implementing and evaluating character culture-based school culture (CBSC) projects in Taiwan. This project integrates the principles of justice, care and discipline development that are influenced by several well-known models of character education programs in America.

Colgan (2003) about Making Character Education Work. Make character education work in research by finding teachers who are committed to character education, who can be flexible in their teaching approaches and focused on providing effective leadership. Singh (2001) about How Character Education Helps Students Grow. The results of this study indicate that as educators can influence students with positive things through the skills they need to become successful adults. 
Chang and Chou (2015) about An Exploratory Study of Young Students 'Core Virtues of E-Character Education: The Taiwanese Teachers' Perspective. The results of this study are exploratory studies, referring to the system of character education/ethics relating specifically to cyberspace (e-character education) and the virtues of e-CE are considered important by teachers regarding legal abortion, respect, self-discipline and sharing.

\section{METHODS}

Research on character education management in Taruna/Taruni at the Politeknik Pelayaran (POLTEKPEL) Surabaya uses a qualitative approach. Qualitative research is research that aims to analyze, understand and express phenomena, events, activities, social, attitudes, and perceptions of thought individually or in groups. The purpose of using qualitative research is to describe, uncover, explain. So, the results in this study illustrate how the management of character education in Taruna/Taruni in Politeknik Pelayaran (POLTEKPEL) Surabaya.

This research is an interactive type of qualitative method that focuses on case studies, because case studies are research conducted in integrated systems of programs, activities, events, or groups of individuals who are bound by a particular place, time, or bond directed to collect data , take meaning, get an understanding of the case.

Research subjects are people who are used as sources of information to uncover facts in the field (Arikunto, 2006: 145). Determination of research subjects or samples in qualitative research was chosen to obtain maximum information not based on statistical calculations.

The data sources in this study were divided into two, namely: 1) the main data sources were obtained in the form of words or verbally and the behavior of the subject (informant) and 2) secondary data sources obtained from photographs, documents and objects used as complementary data sources major (Arikunto, 2010: 130). The main data source in this study was obtained by snowball sampling to select and take samples through the process of rolling from one respondent to another respondent, while secondary data sources in the form of documents, such as books, articles, scientific journals, letters or archives in Politeknik Pelayaran Surabaya. Data collection techniques in this study used three techniques, namely observation, interviews, and documentation (Bogdan and Biklen, 2003: 38).

\section{RESULTS AND DISCUSSION}

Politeknik Pelayaran Surabaya is a university that has a strong commitment to organizing character education programs. This statement is based on research findings obtained through observation, interviews, and documentation studies. The research findings are systematically presented in accordance with the predetermined problem formulation.

\subsection{Planning for Character Education in Creating Ethical Cadets Graduates at Politeknik Pelayaran Surabaya}

In character education management activities, planning is considered very important so that character education can be implemented well. Therefore, the Shipping Polytechnic processes the process of preparing a character education plan through meetings at the beginning of the year, determining the planning of character education programs by involving relevant organizational structures, namely directors and deputy directors, functional position groups (chief of characters) development centers, head of units, administrative staff each unit), supporting units (administration, majors, business development divisions), battalion officers, and cadets tutor (pasuhtar).

Based on the results of interviews with Deputy Director III, at the beginning of each new academic year a coordination meeting (annual meeting) is held as a process of making character education planning. This coordination meeting is intended to determine the effective implementation of work in order to achieve the targets and targets set in both the short and medium term. As stated by Komariah (2011: 93), planning is the process of determining targets to be achieved or achieved in the future.

Program planning and character education activities at Surabaya Shipping Polytechnic refers to the types of activities that contain elements such as objectives, target activities, substance of activities, implementation activities, related parties, organizing mechanisms, organization, time and place and supporting facilities. Character education planning is done by making the entire campus community effective so that it can support the achievement of goals. As explained by Wiyani (2012: 52 ), in the preparation of planning must be done through a series of questions that need to be answered such as: (what) what activities should be carried out, (where) where the activity was carried out, (when) when the activity was carried out, (how) how to do it, (who) who did it and (why) why it needs to be done.

Furthermore, based on the results of interviews and observations made, the planning process undertaken is the preparation of the curriculum. Curriculum development aims to ensure that every component in the curriculum has the same thought in realizing the vision, mission and goals of the education unit. The formulation of the character-based curriculum is outlined in a hidden curriculum integrated in the operational curriculum created by BPSDM.

Based on the opinion of Iwa and Wiyani (2012: 52), planning is what must be done and achieved. To develop planning and curriculum, it is important to disseminate character education. The socialization is carried out to synchronize thoughts and commitments together so that the implementation of character education can be in accordance with planning and thinking, as well as commitments that have been mutually agreed upon. Socialized character education programs include routine 
activities, programmed activities, and spontaneous activities. Based on the explanation that has been submitted, the planning process carried out at Politeknik Pelayaran Surabaya has been carried out well. The college has tried to arrange the planning of character education programs in accordance with management standards for character education.

\subsection{Implementation of Character Education in Creating Ethical Cadets Graduates at Politeknik Pelayaran Surabaya}

Implementation of character education has been done well. The majority of cadets have a strong and good character compared to non-shipping tertiary institutions. The implementation of character education is an embodiment of a plan that has been made and discussed together. In the opinion of Wiyani (2012: 56) the implementation of character education is an activity to change plans into concrete actions to achieve goals effectively and efficiently.

Implementation of character education in Politeknik Pelayaran Surabaya can be taken through three stages, namely: 1) through habituation in daily activities, programmed or spontaneous, 2) through exemplary activities, and 3) learning activities so as to be able to arouse enthusiasm to have better people and increase all the potential it has.

Character education can be integrated with daily habits in the family, dormitory or community. The habit of greeting friends, seniors, and campus residents and guests who come to visit with respect and honest attitude. Cadets can greet more than once according to how many times they meet with others, as well as the infrastructure used by motivational banners, banners that are reminded and prohibited from doing deviant acts, rules of conduct for cadets, fixed daily order is wrong a supporting facility for the application of character education.

In the case of exemplary activities carried out by all campus communities in the form of being present on time to prepare for morning ceremony activities, dress neatly and clean uniforms, complete attributes, maintain cleanliness of the campus environment, familiarize cadets for prayer in congregation at the mosque.

Character values are formed with totality in application through the development of science and technology through learning, such as religious education, Pancasila education, citizenship, Indonesia, safety culture, security and service, so that character values, such as religion, responsibility, discipline, communicative, and honesty can be applied well.

\subsection{Monitoring of Character Education in Creating Ethical Cadets Graduates at Politeknik Pelayaran Surabaya}

Supervision of the implementation of character education in Politeknik Pelayaran Surabaya is going well. The director and his representative indirectly monitor character education activities. Supervision is carried out by the caregivers of cadets (pasuhtar) by providing assistance and observing the implementation of character education every day. As stated by Wiyani (2012: 61), that supervision is an effort to provide an explanation and develop if it finds things that are not true.

The results of supervision are carried out by monitoring the implementation of character education to improve the preparation of programs that have been owned for irregularities found. Therefore, supervision has a very important role in determining the success of the management process.

\subsection{Evaluation of character education in Creating Ethical Cadets Graduates at Politeknik Pelayaran Surabaya}

An evaluation in the implementation of character education in Politeknik Pelayaran Surabaya has been carried out effectively. Politeknik Pelayaran Surabaya measures the success of the implementation of character education that compares the conditions of the early character of cadets with achievement in a certain time, as written in the guidelines for the implementation of character education.

In general, the evaluation aims to develop and improve the quality of character education programs with predetermined planning. This is in accordance with the opinion of Komariah (2009: 95) which explains the evaluation results can be used as information to ascertain whether the actual activities are in accordance with the planned and the achievement of objectives effectively and efficiently.

Evaluation is very instrumental in controlling the deviant behavior encountered when implementing character education as written in the guidelines for implementing character education.

\section{CONCLUSION}

The conclusion of this study states that the management of character education in Politeknik Pelayaran Surabaya has been done well and effectively. This can be seen from the efforts made by the Director of Surabaya Shipping Polytechnic to improve character education through applicable management procedures.

The character education planning made by Politeknik Pelayaran is based on vision, mission through work meetings at the beginning of the year, planning programs with a combination of moral knowledge, moral feelings, and moral actions. Disseminated to equalize opinions, commitments of all education units regarding the division of tasks, responsibilities and provide insights on the concept of character education for Taruna/Taruni and their parents.

Implementation of character education in Politeknik Pelayaran Surabaya is done through habituation in real-life contests on campus. By involving the entire campus community, character characterization can be 
implemented in daily activities, programmed activities, and spontaneous activities. The application of habituation also requires exemplary behavior and cooperation between parents and cadets. Then he integrates character values into intracuricular, co-curricular and extracurricular activities and programs.

Supervision of the implementation of character education is carried out with strict control through the Taruna / Taruni Code of Ethics (PERTIBTAR) as well as the Daily Order for Permanent Traits (PHST). Supervision is carried out by Pasuhtar who oversees the implementation of character education programs for 24 hours in turn.

Evaluation of character education conducted by Surabaya Shipping Polytechnic is very good and effective. If Taruna/Taruni perform deviant behavior directly, then sanctions are immediately given. The head of the character development center always tries to reduce deviant behavior carried out by Taruna/Taruni by setting new regulations.

\section{REFERENCES}

Agboola \& Tsai (2012). Bring Character Education Into Classroom. European Journal of Educational Research Vol. 1, No. 2, 163-170.

Arikunto (2006). Qualitative Research Methods. Jakarta: Earth Literacy

Bogdan and Biklen (2003). Qualitative Research for Education: An Introduction to Theories and Methods. New York: Pearson Education Group.

Chang, Chih-Ming and Chien Chou. 2015. "An Exploratory Study of Young Students' Core Virtues of E-Character Education: The Taiwanese Teachers' Perspective." Journal of Moral Education 44 (4): 1-15 · June 2015

Colgan, Craig (2003). "Making Character Education Work." American School Board Journal. November 2003

Freeman, G. (2014). The Implementation of Character Education and Children's Literature to Teach Bullying Characteristics and Prevention Strategies to Preschool Children: An Action Research Project. Early Childhood Education Journal, 305-316.

Komariah, Aan et al (2011) Educational Management. Bandung: Alfabeta.

Lickona (2016) Character Matters. Jakarta: PT Bumi Aksara.

Lee, Chi-Ming. "The Planning, Implementation and Evaluation of A CharacterBased School

Culture Project in Taiwan". Journal of Moral Education Vol. 38, No. 2, June 2009, pp. 165-184

Pala, Aynur (2011). The Need For Character Education. International Journal Of Social Sciences And Humanity Studies. Vol 3, No 2, 2011 ISSN: 1309-8063
Grow." Association for Supervision and Curriculum Development. Copyright@ 2002 Ebsco Publishing.

Skaggs, G., \& Bodenhorn, N. (2006). Relationships between implementing character education,student behavior, and student achievement. Journal of Advanced Academics, 18(1), 82-114.

Thompson, William G (2002). "The Effects of Character Education on Student Behavior." Electronic Theses and Dissertations. Paper 706.

https://dc.etsu.edu/etd/706

Wiyani, Novan Ardi (2012). Character Education Management: Concepts and Implementation in school. Yogyakarta: PT. Madani Insan Library. 